\title{
IMPLEMENTASI PEMBELAJARAN DALAM MASA PANDEMI COVID- 19 PADA GURU SEKOLAH DASAR
}

\author{
Amelia Wahyu Sejati ${ }^{1}$, Muhroji $^{2}$, Ajib Rosyadi $^{3}$, Desi Tri Wulandari ${ }^{4}$, \\ Muhamad Taufik Hidayat ${ }^{5}$ \\ Muh231@ums.ac.id \\ Pendidikan Guru Sekolah Dasar, Fakultas Keguruan Ilmu Pendidikan, \\ Universitas Muhammadiyah Surakarta
}

\begin{abstract}
Abstrak: Tujuan penelitian ini adalah untuk mengetahui implementasi pembelajaran daring pada masa pandemi dalam aspek spiritual, afektif dan psikomotorik. Jenis penelitian yang digunakan dalam penelitian ini adalah penelitian kualitatif, dengan desain deskriptif. Data yang diperoleh oleh peneliti merupakan data yang berupa data primer dan sekunder dengan teknik pengumpulan data berupa wawancara dan observasi kepada 6 guru sekolah dasar negeri dan swasta yang terbagi pada guru kelas rendah dan kelas tinggi di Kecamatan Rembang, Pati, Purwodadi, Sragen, dan Kota Madya Surakarta. Teknik analisis data yang digunakan adalah 1) Pengumpulan data, 2) Reduksi data, 3) Penyajian data, dan 4) Conclusions, keabsahan data menggunakan triangulasi metode dengan hasil penelitian sebagai berikut: 1) Implementasi pembelajaran daring dalam ranah spiritual berdasarkan hasil wawancara diatas dapat disimpulkan bahwa pencapaian pembelajaran daring pada ranah spiritual berjalan dengan maksimal, 2) Implementasi pembelajaran daring dalam ranah sikap berdasarkan hasil wawancara diatas dapat disimpulkan bahwa pencapaian pembelajaran daring pada ranah sikap berjalan dengan maksimal, dan 3) Implementasi pembelajaran daring dalam ranah ketrampilan berdasarkan hasil wawancara dapat disimpulkan bahwa pencapaian pembelajaran daring pada ranah ketrampilan yang diterima siswa terdapat hasil yang maksimal. Dapat disimpulkan bahwa implementasi pembelajaran dalam masa pandemi covid19 pada guru sekolah dasar dengan pencapaian yang maksimal.
\end{abstract}

Kata kunci: implementasi, pembelajaran, daring

\section{THE IMPLEMENTATION OF INSTRUCTION AT COVID-19 PANDEMIC ERA IN ELEMENTARY SCHOOL}

Abstract: The purpose of this study was to determine the implementation of online learning during the pandemic in spiritual, affective and psychomotor aspects. The type of research used in this study is a qualitative research, with a descriptive design. The data obtained by the researcher is data in the form of primary and secondary data with data collection techniques in the form of interviews and observations to 6 public and private elementary 
Amelia, Muhroji, Ajib, Desi, Taufik. Implementasi Pembelajaran dalam Masa... school teachers who are divided into low grade and high grade teachers in Rembang, Pati, Purwodadi, Sragen, and Madya Districts. Surakarta. The data analysis techniques used are 1) Data collection, 2) Data reduction, 3) Data presentation, and 4) Conclusions, the validity of the data using triangulation methods with research results as follows: 1) Implementation of online learning in the spiritual realm based on the results of the above interview can it can be concluded that the achievement of online learning in the spiritual realm runs optimally, 2) the implementation of online learning in the realm of attitudes based on the results of the interview above, it can be concluded that the achievement of online learning in the realm of attitudes runs optimally, and 3) the implementation of online learning in the realm of skills based on the results of interviews can it can be concluded that the achievement of online learning in the realm of skills received by students has maximum results. It can be concluded that the implementation of learning during the COVID-19 pandemic for elementary school teachers with maximum achievements.

Keywords: implementation, learning, online

\section{PENDAHULUAN}

COVID-19 merupakan penyakit yang menular. Virus jenis baru yang ditemukan di Wuhan, Hubei, China pada tahun 2019 (Ilmiyah, 2020: Hui, et al., 2020). Karena itu, virus Corona diberi nama Corona Virus Disease 2019. Virus ini menyebar secara luas hingga mengakibatkan pandemic secara global yang berlangsung sampai saat ini. Akibat dari pandemic banyak cara yang dilakukan pemerintah untuk mencegah virus tersebut. Bahkan Mentri pendidikan dan kebudayaan menerbitkan Surat Edaran Nomor 3 Tahun 2020 pada Satuan Pendidikan dan Nomor 36962/MPK.A/HK/2020 tentang Pelaksanaan dalam Masa Darurat Corona virus Disease (COVID-19) kegiatan belajar dilaksanakan secara dalam jaringan (daring) dalam mencegahan penyebaran corona virus disease (COVID-19). Hal ini menyebabkan pembelajaran daring untuk semua jenjang pendidikan, terutama Sekolah Dasar (Aji R.H.S, 2020).

Kondisi anak usia Sekolah Dasar mempunyai peluang tinggi untuk mengembangkan berbagai potensi yang dimiliki. Namun akibat dari pandemi ini, WHO merekomendasikan untuk menghentikan kegiatan-kegiatan yang berpotensi menimbulkan kerumunan massa. Sehingga pembelajaran yang dilakukan harus mampu meminimalisir kontak fisik antara siswa dengan siswa lain. Adanya wabah ini, sudah sangat jelas bahwa kegiatan belajar mengajar dilakukan di rumah.Sehingga proses atau strategi dalam pembelajaran ini, menggunakan sistem daring atau melalui online. Hal ini merupakan salah satu keadaan yang tidak diinginkan oleh pengajar. Namun hal ini adalah cara tepat untuk mencegah mata rantai penyebaran virus COVID-19. 
Amelia, Muhroji, Ajib, Desi, Taufik. Implementasi Pembelajaran dalam Masa...

Kondisi ini menjadi permasalahan pembelajaran. Dimana seorang guru harus mampu menyampaikan materi secara jelas dan dapat dimengerti oleh siswanya. Disini peran guru sebagai fasilitator sebagai pilar proses pembelajaaran sangat diutamakan. Dengan demikian, guru harus dapat memberikan media pembelajaran yang efektif pada masa pandemi. Dengan menggunakan keragaman sumber informasi teknologi salah satunya handphone. Barnawi \& Arifin, M. (2012) mengatakan bahwa sikap keprofesionalan guru perlu diterapkan untuk menyeimbangkan antara metode pembelajaran dengan adanya perkembangan zaman. Dengan begitu, kompetensi guru sedang diuji pada saat pembelajaran yang terkesan sulit (Sudrajat, J., 2020).

Dengan adanya perkembangan teknologi salah satunya handphone dapat dimanfaatkan oleh guru sebagai media pembelajaran berbasis Android. Bahkan sebagian dari mereka menggantungkan kepentingan sehari-hari pada kecanggihan dari teknologi (Juliana, 2019). Dalam pembelajaran online pada pelaksanaannya membutuhkan dukungan perangkat-perangkat mobile seperti telepon pintar, tablet dan laptop yang dapat digunakan untuk mengakses informasi dimana saja dan kapan saja (Gikas \& Grant, 2013). Dengan demikian proses pembelajaran dalam masa pandemi akibat COVID-19 masih dapat berjalan lancar.

Berdasarkan uraian diatas, peneliti merumuskan tentang bagaimana implementasi pembelajaran daring pada masa pandemi dalam aspek spiritual, afektif, dan psikomotorik. Tujuan penelitian pada artikel ini adalah untuk mengetahui implementasi pembelajaran daring yang dilakukan oleh guru sekolah dasar pada masa pandemi berdasarkan beberapa aspek yaitu aspek spiritual, afektif, dan psikomotorik.

\section{METODE PENELITIAN}

\section{A. Jenis Penelitian}

Jenis penelitian yang digunakan dalam penelitian ini adalah penelitian kualitatif. Penelitian kualitatif adalah penelitian berpola investigasi dimana data-data dan pernyataan di peroleh dari hasil interaksi langsung antara peneliti, objek yang diteliti dan orang-orang yang ada di tempat penelitian. Menurut Denzin dan Lincoln (2018 dalam Winarni) penelitian kualitatif merupakan penelitian yang menggunakan latar belakang alamiah, dengan maksud menafsirkan fenomena yang terjadi dan dilakukan dengan jalan melibatkan berbagai metode yang ada. Penelitian ini menekankan pada hal 
Amelia, Muhroji, Ajib, Desi, Taufik. Implementasi Pembelajaran dalam Masa... yang terpenting dari suatu barang, jasa berupa kejadian, fenomena, gejala sosial yang dapat dijadikan pelajaran bagi pengembangan konsep teori. (Winarni, 2018)

Desain yang digunakan pada penelitian ini adalah deskriptif. Adapun yang dimaksud dengan deskriptif adalah suatu desain dalam meneliti status sekelompok manusia, suatu obyek, suatu kondisi, suatu sistem pemikiran ataupun suatu kelas peristiwa pada masa sekarang. Tujuan peneliti memilih desain diskriptif adalah untuk membuat deskripsi gambaran atau lukisan secara sistematis, faktual dan akurat menganai fakta-fakta, sifat-sifat serta hubungan antara fenomena yang diselidiki. Hal ini peneliti menggunakan sistem daring dalam mengumpulkan data tentang implementasi pembelajaran dari dalam masa pandemi covid-19 pada guru sekolah dasar.

\section{B. Sumber Data}

Data yang diperoleh oleh peneliti merupakan data yang berupa data primer dan sekunder. Data primer adalah sumber data penelitian yang diperoleh secara langsung dari sumber aslinya yang berupa wawancara secara daring, dan observasi laporan pembelajaran daring. Sedangkan data sekunder adalah sumber data penelitian yang diperoleh melalui media perantara atau secara tidak langsung yang berupa buku, catatan, bukti yang telah ada, atau arsip (Winarni, 2018). Data yang digunakan dalam penelitian ini adalah hasil penelitian observasi dan wawancara terhadap implementasi pembelajaran daring dalam masa pandemi covid-19 pada guru sekolah dasar.

Menurut Moleong (2012) sumber data adalah data yang diperoleh dari informan berupa tindakan atau kata-kata yang berkaitan dengan penelitian. Sumber data dari penelitian ini adalah guru kelas atas (4-6), dan guru kelas bawah (1-3).

\section{Teknik Pengumpulan Data}

Pengumpulan data yang diterapkan sebagai alat pengumpulan data dalam penelitian ini adalah :

1) Observasi

Menurut Nasution, observasi sebagai cara untuk mengumpulkan data dengan mengamati atau mengobservasi objek penelitian atau fenomena baik berupa manusia, benda mati, kegiatan, dan alam (Sugiyono, 2018: 377). Kegiatan observasi dalam penelitian ini yaitu dengan bentuk observasi terhadap laporan pembelajaran daring setiap bulan.

2) Wawancara 
Amelia, Muhroji, Ajib, Desi, Taufik. Implementasi Pembelajaran dalam Masa...

Wawancara merupakan teknik pengumpulan data berupa pertanyaanpertanyaan yang diajukan oleh peneliti secara verbal kepada orang-orang yang dianggap dapat memberikan informasi atau penjelasan hal-hal yang dipandang perlu, dengan tujuan untuk mengetahui hal-hal dari responden secara mendalam (Sugiyono, 2018: 384). Pada penelitian ini, wawancara dilaksanakan secara daring dengan menggunakan aplikasi WhatsApp tentang implementasi pembelajaran daring dalam masa pandemi covid-19.

\section{Instrumen Pengumpulan Data}

Pengumpulan data dalam penelitian ini menggunakan teknik wawancara dan observasi, adapun instrumen yang digunakan dalam pengambilan data sebagai berikut:

Tabel 3.1 Instrumen Pengumpulan Data Wawancara

\begin{tabular}{|c|c|c|}
\hline No. & Aspek & Indikator \\
\hline \multirow{5}{*}{1} & \multirow{5}{*}{ Spiritual } & Berdoa sebelum dan sesudah kegiatan \\
\hline & & Menjalankan ibadah sesuai keyakinan \\
\hline & & Bersyukur \\
\hline & & Mengkolaborasikan dengan orang sekitar \\
\hline & & Menghormati orang yang lebih tua \\
\hline \multirow{5}{*}{2} & \multirow{5}{*}{ Sosial } & Mandiri dalam mengerjakan tugas \\
\hline & & Kedisiplinan dalam mengumpulkan tugas \\
\hline & & Tanggungjawab \\
\hline & & Diskusi dalam sosial media yang digunakan \\
\hline & & Saling membantu oranglain \\
\hline \multirow{5}{*}{3} & \multirow{5}{*}{ Psikomotorik } & $\begin{array}{l}\text { Memberikan contoh dan memerintahkan untuk } \\
\text { menirukan }\end{array}$ \\
\hline & & Menyusun apa saja yang sudah dicontohkan \\
\hline & & Melakukan sesuai dengan prosedur yang disusun \\
\hline & & Tanggungjawab sesuai prosedur \\
\hline & & Praktik secara alami \\
\hline
\end{tabular}

Tabel 3.2 Instrumen Pengumpulan Data Observasi

\begin{tabular}{|c|c|c|}
\hline No. & Aspek & Indikator \\
\hline \multirow{5}{*}{1} & \multirow{5}{*}{ Spiritual } & Berdoa sebelum dan sesudah kegiatan \\
\hline & & Menjalankan ibadah sesuai keyakinan \\
\hline & & Bersyukur \\
\hline & & Mengkolaborasikan dengan orang sekitar \\
\hline & & Menghormati orang yang lebih tua \\
\hline \multirow{5}{*}{2} & \multirow{5}{*}{ Sosial } & Mandiri dalam mengerjakan tugas \\
\hline & & Kedisiplinan dalam mengumpulkan tugas \\
\hline & & Tanggungjawab \\
\hline & & Diskusi dalam sosial media yang digunakan \\
\hline & & Saling membantu oranglain \\
\hline \multirow{5}{*}{3} & \multirow{5}{*}{ Psikomotorik } & $\begin{array}{l}\text { Memberikan contoh dan memerintahkan untuk } \\
\text { menirukan }\end{array}$ \\
\hline & & Menyusun apa saja yang sudah dicontohkan \\
\hline & & Melakukan sesuai dengan prosedur yang disusun \\
\hline & & Tanggungjawab sesuai prosedur \\
\hline & & Praktik secara alami \\
\hline
\end{tabular}

\section{E. Pemilihan Informan}


Amelia, Muhroji, Ajib, Desi, Taufik. Implementasi Pembelajaran dalam Masa...

Dalam pemilihan informan, peneliti memilih dua subjek informan yaitu guru.

Guru yang menjadi informan adalah guru kelas rendah (1-3) dan guru kelas tinggi (4-6) yang sedang mengajar di sekolah dasar dan guru tersebut yang menilai hasil belajar dari peserta didik dalam sistem pembelajaran daring. Kemudian informan yang kedua adalah kepala sekolah yang masih menjabat pada waktu pengambilan data dengan menggunakan sistem daring.

Tabel 3.3 Informan Penelitian Wawancara

\begin{tabular}{|c|c|c|c|c|c|}
\hline No. & Inisial & Gender & Mengajar & Sekolah & Akreditasi \\
\hline 1 & S & Perempuan & Kelas II & SD Negeri di Grobogan & A \\
\hline 2 & LNO & Perempuan & Kelas V & SD Negeri di Grobogan & A \\
\hline 3 & RDJ & Laki-laki & Kelas IV & SD Negeri di Pati & A \\
\hline 4 & AY & Laki-laki & Kelas III & Guru PAI SD Negeri Rembang & A \\
\hline 5 & YAP & Laki-laki & Kelas II & SD Swasta di Surakarta & A \\
\hline 6 & NI & Perempuan & Kelas VI & SD Swasta di Sragen & A \\
\hline
\end{tabular}

\section{Tabel 3.4 Informan Penelitian Observasi}

\begin{tabular}{|c|c|c|c|c|c|c|}
\hline No. & Inisial & Gender & Status & Kelas & Sekolah & Akreditasi \\
\hline 1 & AS & Laki-laki & Siswa & II & SD Negeri di Grobogan & A \\
\hline 2 & FM & Laki-laki & Siswa & II & SD Negeri di Grobogan & A \\
\hline 3 & RD & Perempuan & Siswa & V & SD Negeri di Grobogan & A \\
\hline 4 & YM & Perempuan & Siswa & V & SD Negeri di Grobogan & A \\
\hline 5 & CWP & Perempuan & Siswa & V & SD Negeri di Grobogan & A \\
\hline 6 & RFP & Laki-laki & Siswa & III & SD Negeri di Pati & A \\
\hline 7 & GM & Laki-laki & Siswa & III & SD Negeri di Pati & A \\
\hline 8 & MIP & Laki-laki & Siswa & III & SD Negeri di Pati & A \\
\hline 9 & JN & Perempuan & Siswa & IV & SD Negeri di Rembang & A \\
\hline 10 & YK & Perempuan & Siswa & IV & SD Negeri di Rembang & A \\
\hline 11 & GH & Laki-laki & Siswa & II & SD Swasta di Surakarta & A \\
\hline 12 & MSP & Laki-laki & Siswa & II & SD Swasta di Surakarta & A \\
\hline 13 & QB & Perempuan & Siswa & VI & SD Swasta di Sragen & A \\
\hline 14 & SH & Perempuan & Siswa & VI & SD Swasta di Sragen & A \\
\hline 15 & EKW & Perempuan & Siswa & VI & SD Swasta di Sragen & A \\
\hline
\end{tabular}

\section{F. Analisis Data}

Teknik analisis data yang digunakan dalam penelitian ini yaitu menggunakan teknik analisis data interaktif model dari Miles dan Huberman (Sugiyono, 2010: 337), mereka mengemukakan bahwa aktivitas dalam analisis data kualitatif dilaksanakan secara interaktif dan berlangsung secara terus menerus hingga tuntas, sehingga datanya sudah jenuh. Kegiatan yang dilakukan pada analisis data ini adalah:

1) Pengumpulan data (Data Collection)

Dalam tahap ini peneliti mengumpulkan data melalui observasi laporan pembelajaran daring dan wawancara dengan menggunakan sistem daring.

2) Reduksi Data (Data Reduction) 
Amelia, Muhroji, Ajib, Desi, Taufik. Implementasi Pembelajaran dalam Masa...

Merangkum data yang relevan yang telah diperoleh. Mereduksi data berarti memilah hal-hal pokok, memfokuskan pada hal-hal yang penting, mencari tema dan polanya serta membuang yang tidak diperlukan.Dalam hal ini hasil wawancara yang telah dilakukan dikelompokkan dengan hasil observasi, kemudian dicari tema dan polanya lalu dirangkum sesuai dengan rumusan masalah.

3) Penyajian data (Data Display)

Setelah semua data direduksi, maka tahap selanjutnya yaitu mendisplaykan data, yakni memaparkan data dalam bentuk uraian singkat, hubungan antar kategori, bagan, flowchart, maupun sejenisnya. Penyajian data dalam penelitian kualitatif ini berupa teks naratif yang berisi tentang data-data, informasi dari hasil observasi dan wawancara mengenai implementasi pembelajaran daring dalam masa pandemi covid-19.

4) Conclusions drawing/verifying.

Tahap selanjutnya yaitu menarik kesimpulan atau verifikasi data yang telah dibuat disajikan dalam hasil penelitian. Pemaparan hasil penelitian disertai bukti-bukti yang kuat yang telah dikumpulkan kemudian dibandingkan dengan teori.

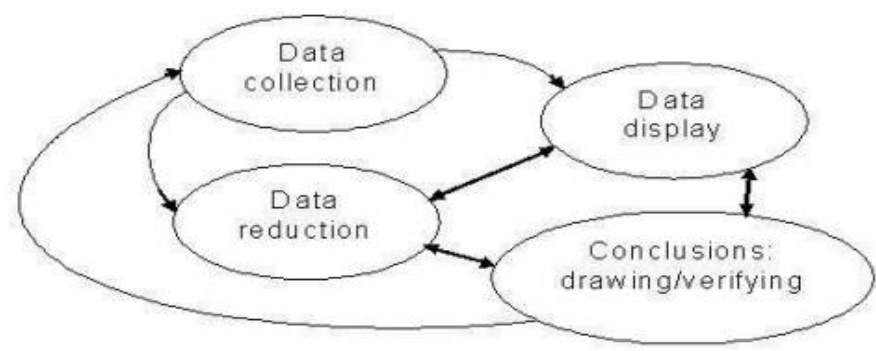

\section{Gambar 1. Model Analisis Data}

Sumber: Miles dan Huberman (dalam Sugiyono, 2010:337)

\section{G. Keabsahan Data}

Instrumen utama pada penelitian kualitatif adalah manusia, karena itu yang diperiksa adalah keabsahan datanya. Untuk menguji kredibilitas data penelitian peneliti menggunakan teknik Triangulasi. Menurut Sugiyono (2018: 397), teknik triangulasi adalah menjaring data dengan berbagai metode dan cara dengan menggabungkan informasi yang diperoleh agar data yang didapatkan lebih lengkap dan sesuai dengan yang diharapkan. Setelah mendapatkan data yang jenuh yaitu keterangan yang 
Amelia, Muhroji, Ajib, Desi, Taufik. Implementasi Pembelajaran dalam Masa... didapatkan dari sumber-sumber data telah sama maka data yang didapatkan lebih kredibel. Teknik triangulasi terdapat beberapa macam, diataranya triangulasi sumber, triangulasi metode, dan triangulasi waktu.

Pada penelitian ini peneliti menggunakan Triangulasi Metode, yaitu dengan membandingkan derajat kepercayaan suatu informasi yang diperoleh dari sumber yang berbeda. Misalnya membandingkan hasil observasi laporan pembelajaran daring dengan hasil wawancara. Dalam penelitian ini, peneliti membandingkan hasil penelitian yang diperoleh dari hasil observasi pada laporan pembelajaran daring, dengan apa yang didapatkan dari hasil wawancara mendalam dengan guru kelas rendah (1-3), guru kelas tinggi (4-6).

\section{HASIL}

Dalam pengambilan data hasil penelitian tentang aspek spiritual, aspek sosial, dan aspek psikomotorik dilakukan pada bulan Juli-September 2020 dengan teknik wawancara kepada 6 (enam) guru kelas kecil dan kelas besar yang terbagi dalam 3 (tiga) Kabupaten, dan 1 (satu) Kota Madya yaitu Grobogan, Pati, Rembang, dan Surakarta. Pengambilan data observasi dilakukan kepada siswa kelas kecil dan siswa kelas besar sebanyak 15 siswa yang terbagi dalam 3 (tiga) Kabupaten, dan 1 (satu) Kota Madya yaitu Grobogan, Pati, Rembang, dan Surakarta. Adapun hasil penelitian sebagai berikut:

\section{Implementasi Pembelajaran Daring pada Aspek Spiritual}

Aspek spiritual dalam berdoa sebelum dan sesudah melakukan kegiatan sudah diberikan dan dilakukan setiap pemberian tugas, pernyataan tersebut diperkuat dalam wawancara terhadap AY guru PAI SD Negeri di Rembang beliau memberikan jawaban sebagai berikut:

"Iya, di setiap pembelajaran, anak-anak itu selalu diberi penjelasan bagaimana cara berdoa untuk mengawali pembelajaran dan nanti diakhir pembelajaran minimal dapat mengucapkan Alhamdulillah untuk menyelesaikan pembelajaran. Disamping itu, berdoa pun harus didampingi oleh orang tua, karena doa sudah ada modulnya yang disampaikan kepada orang tua bagaimana caranya berdoa dengan baik dan benar. Biasanya orang tua diberitahu agar peserta didik dipantau dalam melakukan kegiatan berdoa. Karena di daerah yang tidak terlalu kota besar, belum tentu anak memiliki HP sendiri, disamping itu semuanya tergantung orang tuanya pada saat itu orang tuanya dirumah atau tidak. Dari guru sendiri, setiap pembelajaran, KD, atau pertemuan daring, setiap pemberian 
Amelia, Muhroji, Ajib, Desi, Taufik. Implementasi Pembelajaran dalam Masa...

dari guru itu ada modul untuk panduan berdoa awal bagaimana sikapnya dan nanti selesai belajar bagaimana sikapnya." (AY/GPAI/Rembang)

Aspek spiritual dalam menanamkan untuk menjalankan ibadah sesuai dengan agamanya sudah dilaksanakan, pernyataan tersebut diperkuat dalam wawancara terhadap RDJ guru kelas IV di SD Negeri Pati beliau memberikan jawaban seperti berikut:

"Iya, selalu diingatkan setiap pemberian tugas di pagi hari, tetapi pelaksanaannya di prioritaskan pada waktu sholat maghrib dan Isya bagi peserta didik yang beragama Islam dan memberi himbauan untuk tetap beribadah di rumah di masa pandemi Covid-19 ini." (RDJ/GKIV/Pati)

Aspek spirituan dalam memberikan pelajaran untuk bersyukur sudah diberikan, pernyataan tersebut diperkuat dalam wawancara terhadap LNO guru kelas V SD Negeri di Purwodadi memberikan pendapat seperti berikut:

"Iya. Siswa pastinya akan diselipkan dengan pemberian pelajaran untuk bersyukur. Contohnya: diberikan sebuah cerita tentang kehidupan orang miskin, nah disana siswa dapat mengambil sebuah pesan untuk bersyukur dengan apa yang mereka punyai saat ini." (LNO/GKV/Purwodadi)

2. Implementasi Pembelajaran Daring pada Aspek Sosial

Aspek sosial dalam mengingatkan bahwa tugas itu dikerjakan sendiri sudah dilakukan, pernyataan ini sesuai dalam hasil wawancara AY guru PAI SD Negeri di Rembang memberikan pendapat sebagai berikut:

"Untuk tugas mandiri kepada anak yang harus dikerjakan sendiri, tetapi orang tua harus tetap mendampingi. Anak tidak langsung mengerjakan sendiri tanpa bisa memahami, belum tentu semua anak paham tentang materi yang diberikan oleh guru, jadi orang tua harus mendampinginya. Terkadang ada ditemukan permasalahan yaitu tugas yang diberikan tidak dikerjakan sendiri. Misalnya ketika diberikan tugas untuk membaca dan diminta untuk mengerjakan soal di halaman 5, jika tanpa bimbingan orang tua, anak akan langsng mengerjakan soal di halaman 5 tanpa membaca bacaannya terlebih dahulu. Jadi ketika mengerjakan tugas, orang tua harus mendampingi dan ikut mendengarkan bacaan dari anaknya agar tidak dikerakan dengan asal-asalan. Biasanya sebagian ada ditemukan tulisan berbeda dengan tulisan tangan anak tersebut terjadi ketika anak malas untuk mengerjakan tugas dan orang tua kewalahan. Kemudian guru 
Amelia, Muhroji, Ajib, Desi, Taufik. Implementasi Pembelajaran dalam Masa...

ketika mendapati hal tersebut, akan dikurangi nilainya. Tetapi hal tersebut tetap ada konfirmasi dan himbauan kepada orang tuanya bahwa tugas harus dikerjakan oleh anak, bukan orang tuanya.” (AY/GPAI/Rembang)

Aspek sosial tanggung jawab yang diberikan kepada peserta didik selama pembelajaran daring di rumah, sudah dilaksanakan dengan baik, pernyataan ini sesuai dengan hasil wawancara NI guru kelas VI SD Swasta di Sragen sebagai berikut:

"Untuk aspek sosial tanggungjawab, biasanya saya memberikan beberapa hal, seperti: siswa membantu bersih-bersih rumah, dan mengerjakan tugas sendiri serta menjalankan ibadah secara tepat waktu.” (NI/GKVI/Sragen)

Aspek sosial memberikan tugas untuk membantu sesama manusia yang sedang kesusahan sudah diberikan, pernyataan ini diperkuat dengan hasil wawancara

"Iya, tetapi untuk membatu sesama ketika kesusahan hanya diberikan ketika terdapat materi atau pembelajaran mengenai hal tersebut. Untuk keadaan pandemi seperti ini, diberikan himbauan untuk selalu di rumah, memakai masker ketika bermain di luar atau bepergian, dan sering mencuci tangan.” (YAP/GKII/Surakarta)

3. Implementasi Pembelajaran Daring pada Aspek Psikomotorik

Aspek psikomotorik tentang memberikan contoh dan memerintahkan peserta didik untuk menirukan sudah dilakukan, hal ini diperkuat dari hasil wawancara NI guru kelas IV SD Swasta di Sragen sebagai berikut:

"Iya, ketika pemberian tugas untuk ditirukan siswa, biasanya guru memberikan contoh tutorial video. Contohnya: siswa diberikan contoh video untuk mencuci tangan secara teratur dan dalam langkah yang benar. Setelah itu siswa diwajibkan untuk membuat tutorial video yang sama, setelah itu dikirimkan dalam bentuk video." (NI/GKVI/Sragen)

Aspek Psikoomotorik memerintahkan untuk menyusun apa saja yang sudah dicontohkan sudah terlaksana, pernyataan tersebut diperkuat dari hasil wawancara yang dilakukan oleh S guru kelas II SD Negeri di Purwodadi sebagai berikut:

"Iya, biasanya seperti melanjutkan titik-titik kosong. Seperti nama siti, huruf S dan selanjutnya huruf kedua dikosongi, hal ini untuk membuat siswa mengisi kolom huruf yang kosong tersebut. Jadi siswa diminta untuk melengkapi huruf tersebut menjadi kata." (S/GKII/Purwodadi) 
Amelia, Muhroji, Ajib, Desi, Taufik. Implementasi Pembelajaran dalam Masa...

Aspek Psikoomotorik tentang memberikan tugas yang bersifat praktik secara alami sudah diberikan dalam pembelajaran daring, hal ini diperkuat dalam hasil wawancara AY guru PAI SD Negeri di Rembang sebagai berikut:

"Terkadang dalam pelajaran agama terdapat banyak kegiatan pratiknya, seperti praktek sholat, mulai dari rukunnya, bagaimana gerakannya, bagaimana bacaannya, waktunya seperti apa. Untuk kelas 3, praktiknya dapat dilakukan yaitu guru mengirimkan di grup WA sebuah gambar gerakan kemudian guru meminta untuk peserta didik menirukan dan divideokan lalu dikirimkan ke guru." (AY/GPAI/Rembang)

\section{PEMBAHASAN}

\section{Pencapaian Pembelajaran Daring pada Ranah Spiritual}

Implementasi pembelajaran daring dalam ranah spiritual berdasarkan hasil wawancara diatas dapat disimpulkan bahwa pencapaian pembelajaran daring pada ranah spiritual berjalan dengan maksimal. Hasil tersebut mempunyai kesamaan dengan penelian dari Rosali (2020) tentang Pembelajaran Daring pada Masa Pandemi Covid-19 dengan hasil pembelajaran daring dinilai efektif jika diterapkan pada masa pandemi covid-19 namun diperlukan model yang lebih variatif agar tetap menarik jika digunakan dalam jangka panjang. Menurut Khusniyah (2009), pembelajaran daring yang dilaksanakan pada saat pandemi juga efektif apabila dibarengi dengan ketekunan pendidikan dan peserta didik.

Beberapa faktor yang dapat mempengarui aspek spiritual diantaranya kebiasaan berfikir, bersikap, berkata dan bertindak. Aspek spiritual dapat berubah sesuai dengan keinginan seseorang, jika seseorang mau merubahnya dengan cara berlatih membiasakan diri dengan hal yang baru. Kebiasaan tersebut nantinya akan mempengarui karakteristik serta pribadi individu (Kusmiran, E., 2015: 78).

\section{Pencapaian Pembelajaran Daring pada Ranah Sosial}

Implementasi pembelajaran daring dalam ranah sikap berdasarkan hasil wawancara diatas dapat disimpulkan bahwa pencapaian pembelajaran daring pada ranah sikap berjalan dengan maksimal. Hasil tersebut mempunyai kesamaan dengan penelian dari Sobron, Bayu, Rani, \& Meidawati (2019) tentang persepsi siswa dalam studi pengaruh daring learning terhadap minat belajar IPA dengan hasil pembelajaran daring 
Amelia, Muhroji, Ajib, Desi, Taufik. Implementasi Pembelajaran dalam Masa...

learning dirasa sangat efektif dan efisien karena dapat dilakukan dimana saja dan kapan saja.

Menurut Suwandi (2010:80) sikap dalam pembelajaran dapat dinilai dari sikap terhadap mata pelajaran, terhadap guru atau pengajar, terhadap pembelajaran, dan berkaitan nilai atau norma berhubungan dengan mata pelajaran. Sementara itu, perubahan sikap pada peserta didik hanya diukur dengan menggunakan teknik non-tes. Untuk penilaian sikap atau afektif bisa menggunakan teknik non-tes. Menurut Arifin (2012: 180) teknik non-tes ini bisa dilakukan dengan beberapa kegiatan diantaranya yaitu observasi, wawancara, skala sikap, daftar cek, skala penilaian, angket, studi kasus, catatan insidental, sosiometri, inventori kepribadian, dan teknik pemberian penghargaan kepada peserta. Yuangga (2020) menambahkan bahwa strategi yang dapat digunakan dalam meningkatkan interaksi antara guru dan peserta didik yaitu dengan media yang pemanfaatannya sangat mempengaruhi hasil pembelajaran daring.

\section{Pencapaian Pembelajaran Daring pada Ranah Psikomotorik}

Implementasi pembelajaran daring dalam ranah ketrampilan berdasarkan hasil wawancara dapat disimpulkan bahwa pencapaian pembelajaran daring pada ranah ketrampilan yang diterima siswa terdapat hasil yang maksimal. Hasil tersebut mempunyai kesamaan dengan penelian dari Jethro, Grace \& Thomas (2012) tentang ELearning dan Dampaknya pada Pengajaran dan Belajar di Era Global menunjukkan hasil bahwa e-learning menawarkan berbagai alat untuk memungkinkan guru dan peserta didik menjadi inovatif, kreatif dan banyak akal dalam semua kegiatan pembelajaran. Guru dan peserta didik dapat dengan mudah menyesuaikan sumber belajar digital agar sesuai dengan kecepatan dan level, sesuai untuk pembelajaran apapun gaya dan kemampuan. Hal ini juga memiliki kesamaan dengan penelitian Agarwal \& Pandey (2013) tentang Dampak E-Learning dalam Pendidikan E-learning memiliki berbagai keunggulan lebih dari teknik pembelajaran tradisional dan lebih unggul. Mulyani (2013) juga menyebutkan bahwa pengaruh e-learning yang positif akan mengahasilkan pembelajaran yang maksimal.

Penilaian psikomotorik merupakan penilaian terhadap keterampilan dan kemampuan bertindak setiap individu. Penilaian psikomotorik berkenaan dengan keterampilan-keterampilan bertindak setelah peserta didik menerima pengalaman belajar tertentu. Menurut Sudjana (2009 : 30-31) ada enam tingkatan keterampilan yaitu (1) gerak reflek, (2) gerakan-gerakan dasar, (3) kemampuan perseptual, (4) kemampuan 
Amelia, Muhroji, Ajib, Desi, Taufik. Implementasi Pembelajaran dalam Masa...

dibidang fisik, (5) gerakan-gerakan skill, (6) kemampuan yang berkenaan dengan

komunikasi.

\section{KESIMPULAN}

Berdasarkan hasil dan pembahasan maka dapat disimpulkan tentang implementasi pembelajaran dalam masa pandemi covid-19 pada guru sekolah dasar sebagai berikut:

1) Implementasi pembelajaran daring dalam ranah spiritual berdasarkan hasil wawancara diatas dapat disimpulkan bahwa pencapaian pembelajaran daring pada ranah spiritual berjalan dengan maksimal.

2) Implementasi pembelajaran daring dalam ranah sikap berdasarkan hasil wawancara diatas dapat disimpulkan bahwa pencapaian pembelajaran daring pada ranah sikap berjalan dengan maksimal.

3) Implementasi pembelajaran daring dalam ranah ketrampilan berdasarkan hasil wawancara dapat disimpulkan bahwa pencapaian pembelajaran daring pada ranah ketrampilan yang diterima siswa terdapat hasil yang maksimal.

\section{DAFTAR RUJUKAN}

Agarwal, H., \& Pandey, G. N. (2012) Impact of e-learning in Education. International Journal.

Aji, R. H. S. (2020). Dampak COVID-19 pada pendidikan di indonesia: Sekolah, keterampilan, dan proses pembelajaran. Salam: Jurnal Sosial dan Budaya Syar-i.(7), $5,395-402$.

Arifin, Z. (2012). Evaluasi Pembelajaran : Prinsip Teknik Prosedur. Bandung: Remaja Rosdakarya.

Barnawi \& Arifin, M. (2012). Etika dan profesi kependidikan. Jogjakarta: Ar-Ruzz Media.

Gikas, J.,\& Grant, M. M. (2013). Mobile computing device in higher education: Student perspectives on learning with cellphones, smartphones \& social media. Internet and Higher Education, 19, 18-26.

Ilmiyah, S. (2020). Surotul Ilmiyah - PBNU Menjawab Tantangan Virus Corona. Dipetik April 18, 2020, dari YouTube alobatnic: https://youtu.be/SPdc4WT8BCg. 
Amelia, Muhroji, Ajib, Desi, Taufik. Implementasi Pembelajaran dalam Masa...

Jethro, O. O., Grace, A. M., \& Thomas, A. K. (2012). E-learning and its effects on teaching and learning in a global age. International Journal of Academic Research in Business and Social Sciences, 203-210.

Juliana, D. Dewi, K. Siti. (2019). "Pengenalan Cerita Rakyat dan Game Edukasi Untuk Anak Menggunakan Android”. Jurnal Ilmiah Informatika Vol. 14(2): Hal. 103-110.

Kusmiran, E. (2015). Soft skills caring dalam pelayanan keperawatan. Jakarta: Trans Info Media.

Khusniyah, L. N, Hakim, L. (2019). Efektivitas Pembelajaran Berbasis Daring: Sebuah Bukti pada Pembelajaran Bahasa Inggris. Jurnal Tatsqif, 17(1), 19-33.

Menteri Pendidikan. (2020). Surat Edaran Nomor 3 Tahun 2020 Tentang Pelaksanaan Pendidikan dalam Masa Darurat Corona Virus (COVID-19).

Moleong, L. (2012). Metodologi Penelitian Kualitatif. Bandung: PT. Remaja Rosdakarya.

Rosali, E. S. (2020). Aktifitas Pembelajaran daring pada masa pandemi covid-19 di jurusan pendidikan geografi universitas siliwangi Tasikmalaya. Geosee, 1(1).

Sobron, A.N, Bayu, Rani, Meidawati,S. (2019). Persepsi Siswa dalam Studi Pengaruh Daring Learning Terhadap Minat Belajar IPA. SCAFFOLDING: Jurnal Pendidikan Islam dan Multikulturalisme Vol. 1, No. 2, hh. 30-38.

Sudjana, N. (2009). Penilaian Hasil Proses Belajar Mengajar. Bandung: PT. Remaja Rosdakarya.

Sudrajat, J. (2020). Kompetensi Guru Di Masa Pandemi Covid-19. Jurnal Riset Ekonomi dan Bisnis, 13(1), 100-110.

Sugiyono. (2018). Metode Penelitian Manajemen. Bandung: Alfabeta.

Suwandi, S. (2010). Model assesmen dalam pembelajaran. Surakarta: Yuma Pustaka.

Winarni, Z. (2018). Apa, Mengapa, dan Bagaimana. Prosiding Semnas Pendidikan IPA Pascasarjana UM. 1(1): 976-98.

Yuangga, K. D., \& Sunarsi, D. (2020). Pengembangan media dan strategi pembelajaran untuk mengatasi permasalahan pembelajaran jarak jauh di pandemi covid-19. JGK (Jurnal Guru Kita), 4(3), 51-58. 